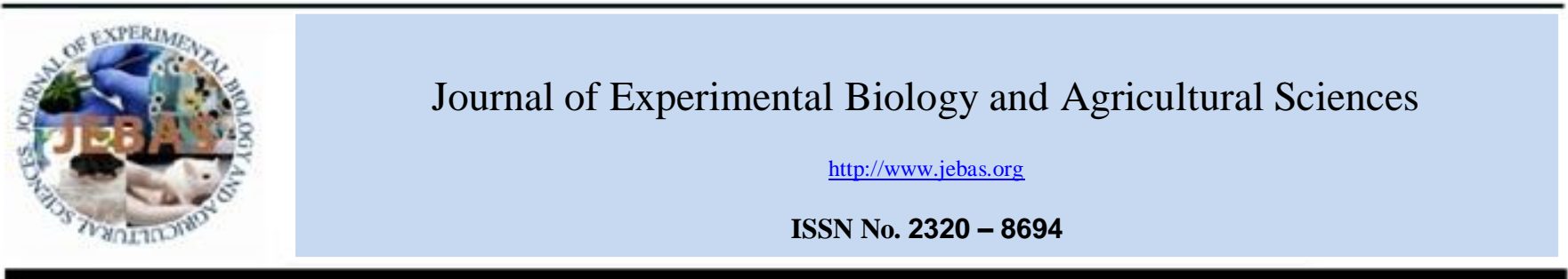

\title{
ASSESSMENT OF HUMORAL IMMUNE RESPONSE IN VACCINATED DOMESTIC DOGS AND CATS INTENDED FOR PET-TRAVEL FROM INDIA BY RAPID FLORESCENT FOCUS INHIBITION TEST (RFFIT)
}

\author{
Santosh $\mathrm{AK}^{1}$, Isloor $\mathrm{S}^{1}$, ${ }^{*}$ Rathnamma $\mathrm{D}^{1}$, Sharada $\mathrm{R}^{3}$, Sunilkumar $\mathrm{KM}^{6}$, Balamurugan $\mathrm{V}^{4}$, \\ Yathiraj $S^{5}$, Satyanarayana $\mathrm{ML}^{2}$
}

\footnotetext{
${ }^{1}$ KVAFSU-CVA-Crucell Rabies Diagnostic Laboratory, Dept. of Microbiology, Veterinary College, KVAFSU, Hebbal, Bengaluru, Karnataka

${ }^{2}$ Department. of Pathology, Veterinary College, KVAFSU, Hebbal, Bengaluru, Karnataka

${ }^{3}$ Department of Microbiology, Veterinary College, KVAFSU, Hassan, Karnataka

${ }^{4}$ National Institute of Veterinary Epidemiology and Disease Informatics, Ramagondanahalli, Bengaluru

${ }^{5}$ Veterinary College, KVAFSU, Hebbal, Bengaluru, Karnataka

${ }^{6}$ Department of Animal Husbandry and Veterinary Services, Government of Karnataka, Shikaripura, Karnataka
}

Received - May 30, 2017; Revision - August 27, 2017; Accepted - October 07, 2017

Available Online - October 31, 2017

http://dx.doi.org/10.18006/2017.5(5).606.613

\section{KEYWORDS \\ Anti-rabies vaccinal antibodies \\ RFFIT \\ Dogs \\ Cats}

Pet travel

\begin{abstract}
The present study evaluates humoral response in vaccinated domestic dogs and cats intended for pettravel from India by Rapid Fluorescent Focus Inhibition Test (RFFIT). In present study, 184 serum samples from $\operatorname{dogs}(n=149)$ and cats $(n=35)$, vaccinated within the period of one year against rabies were tested by RFFIT using PV-3462 strain of rabies virus and BHK 21 cells. Out of total studied 149 dogs samples (male-96, female-53), 122 showed titre $\geq 0.5 \mathrm{IU} / \mathrm{ml}$ and 27 below $<0.5 \mathrm{IU} / \mathrm{ml}$. Interestingly, all the 35 samples from cats showed titre $\geq 0.5 \mathrm{IU} / \mathrm{ml}$. The protection observed in vaccinated dogs was 81.87 per cent and in vaccinated cats it was 100 per cent. The analysis showed serum sampling between 20-50 days will have higher percentage of vaccinates with neutralizing antibody titre $\geq 0.5 \mathrm{IU} / \mathrm{ml}$ than those collected < 20 days and $>50$ days. Association of the age factor of the vaccinated dogs and getting varied neutralizing antibody titre was evident. Whereas gender and breed based on size did not reveal any statistically significant effect on antibody titre. Furthermore, Out of eight vaccine brands, only one (V8) yielded 100 percent (9/9) protection, whereas the remaining
\end{abstract}

* Corresponding author

E-mail: kisloor@gmail.com (Isloor S)

Peer review under responsibility of Journal of Experimental Biology and Agricultural Sciences.

Production and Hosting by Horizon Publisher India [HPI] (http://www.horizonpublisherindia.in/).

All rights reserved.
All the article published by Journal of Experimental Biology and Agricultural Sciences is licensed under a Creative Commons Attribution-NonCommercial 4.0 International License Based on a work at www.jebas.org.

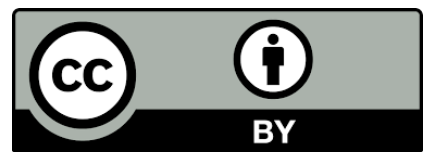


seven resulted in 61.53 (8/13 in V1) to 90.90 (10/11 in V6) percent protection. The failure to protect 18.13 (27 / 149) per cent of dogs even after vaccination is alarming. The exact cause for failure to protect these vaccinated dogs is unknown; the possible reasons could be attributed to age, genetic profile, and brand of vaccine used and non-maintenance of cold chain of vaccine / sample of animal.

\section{Introduction}

Rabies is one of the terrifying infectious disease that has affected mankind since antiquity (Jackson, 2016). Yearly 60,000 human deaths due to rabies are reported worldwide (Hampson et al., 2015), of which 20,000 deaths are from India alone which accounts for one third of total deaths by rabies (Sudarshan et al., 2007; Sudarshan, 2017). Rabies is caused by virus belonging to family Rhabdoviridae and genus Lyssavirus causes acute progressive viral encephalitis (Rupprecht et al., 2002). The virus is made of five structural proteins among which glycoprotein is important major structural protein involved in induction of production and protection against rabies virus by anti-rabies neutralizing antibodies after vaccination (Perrin et al., 1985; Etessami et al., 2000). International travel and trade have increased dramatically during the past two decades. Global travel and trade present risks for rapid, long distance movement of a variety of infectious diseases including rabies virus (IMNA, 2010). Due to this, in the past few years, serological testing of dogs and cats has increased because many rabies free countries have amended their quarantine measures and adopted a scheme requiring rabies vaccination followed by a serological test (Mansfield et al., 2004). This scheme has been promoted by the WHO, OIE and the European Commission and allows the free movement of pets from countries without rabies, or where rabies is under control, to rabies-free countries. Pre-exposure vaccination is considered successful by WHO and OIE when the neutralizing antibody titre is at least $0.5 \mathrm{IU} / \mathrm{ml}$ in serum from vaccinated humans and animal (WHO, 2005; OIE, 2008). Rapid fluorescent focus inhibition test (RFFIT) is a gold standard test which is recommended for serological testing of pets intended for international trade (European Commission, 2003).

Any pet animal moving from India to most other countries is vaccinated and neutralizing antibodies checked for protective neutralizing antibody titre. In India, KVAFSU- CVA- Crucell Rabies diagnostic Laboratory, (a laboratory twinned under OIE programme with APHA, UK, and CDC, Atlanta) Veterinary college, Bangalore is regularly processing serum samples for RFFIT from different states. The present study was conducted to estimate the neutralizing antibodies to anti rabies vaccination in domestic dogs and cats from different states of India which were primarily intended to travel abroad.

\section{Materials and Methods}

\subsection{Collection of Serum samples}

Serum samples $(n=184)$ of vaccinated dogs and cats from 11 different states of India were submitted to KVAFSU-CVACrucell Rabies Diagnostic Laboratory, Veterinary college, Bengaluru along with details of age, gender, breed, history of vaccination, date of serum collection and Microchip number. Of these 184 serum samples, 149 were from dogs (Males-96, Females - 53) and 35 from cats (Males - 18, Female - 17). These serum samples were stored at $-20{ }^{\circ} \mathrm{C}$ until the test was performed

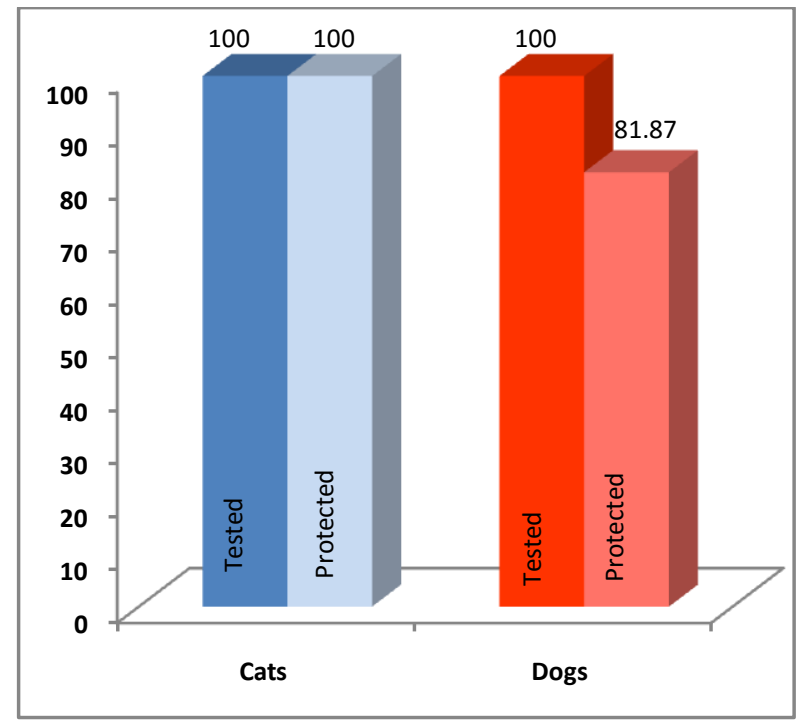

Figure 1 Results of anti- rabies neutralizing antibodies in dogs and cats

\subsection{Rapid Fluorescent Focus Inhibition Test (RFFIT)}

The RFFIT which is gold standard test was employed to assess the neutralizing antibodies against rabies according to Smith et al., 1996 and Neelufer et al., 2015. Initially, the test serum samples were diluted two fold and heat inactivated at $56^{\circ} \mathrm{C}$ for $30 \mathrm{~min}$ followed by further two fold serial dilution viz, 1:2, 1:4, 1:8, 1;16 in the 96 micro titre plate was carried out in duplicate and mixed 
with 100 TCID $_{50}$ constant amount of PV-3462 (Dr. Larghi's strain) of rabies virus obtained from Pasteur Institute, Coonoor, Tamil Nadu. This was incubated for 90 minutes at $37^{\circ} \mathrm{C}$ for virus neutralization. Then $50 \mu \mathrm{l}$ of BHK-21cells $(25,000-30,000)$ suspended in $10 \%$ growth medium was added and incubated for $48 \mathrm{hrs}$ at $37^{\circ} \mathrm{C}$ in $5 \% \mathrm{CO}_{2}$. The contents were then removed and $70 \%$ chilled acetone added to the wells and fixed for 30 minutes in $-20{ }^{\circ} \mathrm{C}$. Then $50 \mu 1$ of Rabies anti-nucleocapsid based conjugate (Light diagnostic rabies DFA III cat \# 6500) was diluted 1:100 with phosphate buffer saline (PBS) along with Evans blue as a counter stain at concentration of $0.001 \%$ and incubated at $37{ }^{\circ} \mathrm{C}$ for one hour. The microtitre plate was then washed with 1x PBS two times, observed under fluorescent microscope at 20X objective.

The neutralising antibody titre of test serum sample was determined by dividing the reciprocal of highest dilution of serum sample by reciprocal of highest dilution of WHO reference serum at which complete neutralization observed, then multiplied by unitage of WHO reference serum. The neutralising antibody titre was expressed in International Unit (IU) / millilitre of test serum. A antibody titre of equal or above $0.5 \mathrm{IU} / \mathrm{ml}$ was considered as protective.

\subsection{Statistical analysis}

A linear model was fitted with various factors like age, gender, breed and brand of vaccine with neutralizing antibody titre. GraphPad Prism-5 software was utilized for calculating mean, standard deviation, standard error. Chi-square $\left(\chi^{2}\right)$ test was employed to detect effect of breed, gender, vaccine brand and association between time intervals for blood sampling and antibody titre. A $\chi^{2}$ test was used to analyze difference among the variables (Version 5; Graphpad Software Inc., La Jolla, CA, USA). The $\mathrm{p}$ value less than 0.05 concluded as statistically significant where as vice versa as statistically non-significant.

\section{Results}

Out of 149 vaccinated dogs, 122(81.87\%) dogs possessed antirabies neutralising antibody titre of $\geq 0.5 \mathrm{IU} / \mathrm{ml}$. Interestingly, all $35(100 \%)$ vaccinated cats had neutralising antibody titre $\geq 0.5 \mathrm{IU} / \mathrm{ml}$

\subsection{Persistence of anti-rabies neutralizing antibodies and best window period for serum collection}

The animals were divided into 3 sampling time groups viz., short, normal and long. This analysis showed that the 20-50 days sampling period had a higher percentage of dogs with neutralizing antibody titre $\geq 0.5 \mathrm{IU} / \mathrm{ml}$ _than the other two groups in dogs (Table 1). This is the best window period for sampling which is having least failure rates (14.55 per cent) with in dogs and higher mean antibody titre $(8.654 \mathrm{IU} / \mathrm{ml})$ in cats.

Data were assessed in terms of protective or non-protective percentage of neutralizing antibody and mean neutralising antibody titre (Table 2). In the present study, the data was tabulated and analysed for association of various factors with antineutralising antibody titre. The statistical analysis with chi square test suggests that there is association of age of vaccinated dog and protective neutralizing antibody titre is not significant because $\mathrm{p}$ values for this is less than 0.05. The adult (1 year -5 years) and older ( $>5$ years) dogs revealed a higher percentage of dogs with neutralizing antibody titre $\geq 0.5 \mathrm{IU} / \mathrm{ml}$ at 76.38 and 94.47 respectively compared to young dogs with 65

Table 1 Best window period for serum sampling to find out neutralizing antibody titre.

\begin{tabular}{|c|c|c|c|c|c|c|c|c|}
\hline & & $\begin{array}{c}\begin{array}{c}\text { No. of } \\
\text { animals }\end{array} \\
\text { with } \\
\geq 0.5 \mathrm{IU} / \mathrm{ml}\end{array}$ & $\begin{array}{c}\begin{array}{c}\text { No. of } \\
\text { animals }\end{array} \\
\text { with } \\
<0.5 \mathrm{IU} / \mathrm{ml}\end{array}$ & Total & Mean Titre & Std error & Per cent & $\begin{array}{c}\text { Chi square } \\
\text { Test }\end{array}$ \\
\hline \multirow{2}{*}{$\begin{array}{l}\text { Below } 20 \text { days } \\
\text { (Short) }\end{array}$} & Dogs & 05 & 02 & 07 & 1.500 & 0.6892 & 71.42 & $\begin{array}{c}\text { Dogs } \\
0.5742^{\text {ns }}\end{array}$ \\
\hline & Cats & 02 & 00 & 02 & 2.250 & 1.750 & 100 & \\
\hline \multirow{2}{*}{$\begin{array}{l}\text { 20-50 days } \\
\text { (Normal) }\end{array}$} & Dogs & 47 & 08 & 55 & 2.330 & 0.4739 & 85.45 & \\
\hline & Cats & 13 & 00 & 13 & 8.654 & 3.075 & 100 & \\
\hline \multirow{2}{*}{$\begin{array}{l}>50 \text { days } \\
\text { (Long) }\end{array}$} & Dogs & 70 & 17 & 87 & 2.477 & 0.2940 & 80.45 & \\
\hline & Cats & 20 & 00 & 20 & 2.625 & 0.8069 & 100 & \\
\hline Total & & 157 & 27 & 184 & & & & \\
\hline
\end{tabular}

Journal of Experimental Biology and Agriculture Science http://www.jebas.org 
Table 2 Effect of age, gender, brand of vaccine, and breed of animals on neutralizing antibody titre of vaccinated dogs

\begin{tabular}{|c|c|c|c|c|c|c|c|c|}
\hline Factors & Levels & $\begin{array}{c}\text { No. of } \\
\text { dogs with } \\
\geq 0.5 \mathrm{IU} / \mathrm{ml}\end{array}$ & $\begin{array}{l}\text { No. of dogs } \\
\text { with } \\
<0.5 \mathrm{IU} / \mathrm{ml}\end{array}$ & Total & $\begin{array}{c}\text { Mean } \\
\text { Titre }\end{array}$ & Std error & $\begin{array}{c}\text { Percent } \\
\text { Protection }\end{array}$ & $\begin{array}{c}\text { Chi square } \\
\text { test }\end{array}$ \\
\hline \multirow{3}{*}{ Age } & Young $(\leq 1$ year $)$ & 13 & 07 & 20 & 2.654 & 0.863 & 65.00 & \multirow{3}{*}{$0.0222^{* *}$} \\
\hline & $\begin{array}{l}\text { Adult (1 year- } \\
\text { 5years) }\end{array}$ & 57 & 17 & 74 & 1.824 & 0.246 & 76.38 & \\
\hline & Older $(>5$ years $)$ & 54 & 03 & 57 & 2.426 & 0.491 & 94.47 & \\
\hline \multirow{2}{*}{ Gender } & Male & 77 & 19 & 96 & 1.821 & 0.260 & 80.20 & \multirow{2}{*}{$0.5148^{\mathrm{ns}}$} \\
\hline & Female & 45 & 08 & 53 & 1.841 & 0.228 & 84.90 & \\
\hline \multirow{8}{*}{$\begin{array}{l}\text { Vaccine } \\
\text { brand }\end{array}$} & V1 & 08 & 05 & 13 & 1.688 & 0.3889 & 61.53 & \multirow{8}{*}{$0.2074^{\mathrm{ns}}$} \\
\hline & $\mathrm{V} 2$ & 35 & 04 & 39 & 1.714 & 0.2063 & 89.74 & \\
\hline & V3 & 21 & 04 & 25 & 1.571 & 0.3507 & 84.00 & \\
\hline & $\mathrm{V} 4$ & 13 & 03 & 16 & 1.769 & 0.5846 & 81.25 & \\
\hline & V5 & 12 & 04 & 16 & 1.682 & 0.3889 & 75.00 & \\
\hline & V6 & 10 & 01 & 11 & 2.167 & 0.8079 & 90.90 & \\
\hline & V7 & 07 & 03 & 10 & 1.286 & 0.4983 & 70.00 & \\
\hline & V8 & 09 & 00 & 09 & 1.333 & 0.3909 & 100.00 & \\
\hline \multirow{3}{*}{ Breed } & Large & 07 & 02 & 09 & 1.667 & 0.4859 & 77.77 & \multirow{3}{*}{$0.2117^{\mathrm{ns}}$} \\
\hline & Medium & 56 & 13 & 69 & 1.604 & 0.2057 & 81.15 & \\
\hline & Small & 50 & 10 & 60 & 1.810 & 0.2432 & 83.33 & \\
\hline
\end{tabular}

per cent. Whereas, gender, brand of vaccine, breed, had no statistical effect $(p>0.05)$.

3.2. Effect of age, gender, brand of vaccine, and breed of animals on neutralizing antibody titre in vaccinated cats

Interestingly, all the 35 cats were having the protective titre of neutralising antibody against rabies (Table 3 ). The mean titre of adult cats was high compared to young and old. Both the genders showed similar protective neutralizing antibody titre and vaccine brands viz., V2, V3, V1, and V4 resulted in higher mean antibody titre in decreasing order. In breed wise analysis, non-descript cats revealed good mean antibody titre than the Persian and domestic short hair.

\subsection{State wise - neutralizing antibody titres in dogs}

The maximum number of serum samples were received from Maharashtra (59) and Karnataka (54) with protective neutralizing antibody titre showing (51/59) 86.44, (44/54) 81.48 percent respectively. From other 8 states the serum samples received varied from 01 to 10 . It indicates more number of pets from Maharashtra and Karnataka are being transported out of India compared to other states (Table 4).

\section{Discussion}

The study was conducted to estimate the neutralizing antibodies to anti rabies vaccination in dogs and cats intended to travel abroad from India. Interestingly, all the cats $(n=35)$ were showing titre above or equal to $0.5 \mathrm{IU} / \mathrm{ml}$ which is required and recommended by OIE and WHO for protection (WHO, 2005; OIE, 2008). In dogs $(n=149), 81.87$ per cent revealed protective titre of neutralizing antibodies. This confirms that cats respond better than dogs as observed by Cliquet et al. (2003). Similar study was conducted in United Kingdom by Mansfield et al. (2004) and obtained 95.88, 94.83 percent of vaccinated dogs and 97.17, 97.33 percent of vaccinated cats showing protective antibody titre tested 
Table 3 Effect of age, gender, brand of vaccine, and breed of animals on neutralizing antibody titre in vaccinated Cats

\begin{tabular}{|c|c|c|c|c|c|c|}
\hline Factors & Levels & $\begin{array}{c}\text { No. of cats with } \\
\geq 0.5 \mathrm{IU} / \mathrm{ml}\end{array}$ & $\begin{array}{c}\text { No. of cats with } \\
<0.5 \mathrm{IU} / \mathrm{ml}\end{array}$ & Total & Mean Titre & Std error \\
\hline \multirow{3}{*}{ Age } & Young ( $\leq 1$ year) & 2 & 0 & 2 & 0.50 & 0 \\
\hline & Adult (1 year- 5years) & 25 & 0 & 25 & 5.75 & 1.788 \\
\hline & Older (>5 years $)$ & 8 & 0 & 8 & 2.50 & 0.763 \\
\hline \multirow{2}{*}{ Gender } & Male & 18 & 0 & 18 & 4.306 & 1.712 \\
\hline & Female & 17 & 0 & 17 & 5.882 & 2.035 \\
\hline \multirow{4}{*}{ Vaccine brand } & V1 & 7 & 0 & 7 & 4.35 & 1.996 \\
\hline & V2 & 6 & 0 & 6 & 11 & 4.669 \\
\hline & V3 & 4 & 0 & 4 & 9.2 & 7.587 \\
\hline & V4 & 4 & 0 & 4 & 3.125 & 1.663 \\
\hline \multirow{3}{*}{ Breed } & Persian & 10 & 0 & 10 & 5.25 & 1.828 \\
\hline & Non Descript & 5 & 0 & 5 & 8.2 & 5.97 \\
\hline & DSH & 14 & 0 & 14 & 4.75 & 2.204 \\
\hline
\end{tabular}

Table 4 State wise protective neutralizing antibody titre of dogs

\begin{tabular}{|c|c|c|c|c|c|}
\hline S. No & State & $\begin{array}{c}\text { No. of animals with } \\
\geq 0.5 \mathrm{IU} / \mathrm{ml}\end{array}$ & $\begin{array}{c}\text { No. of animals with < } \\
0.5 \mathrm{IU} / \mathrm{ml}\end{array}$ & Total & Per cent protected \\
\hline 1. & Maharashtra & 51 & 08 & 59 & 86.44 \\
\hline 2. & Karnataka & 44 & 10 & 54 & 81.48 \\
\hline 3. & Haryana & 07 & 00 & 07 & 100 \\
\hline 4. & Andra Pradesh & 03 & 01 & 04 & 75.00 \\
\hline 5. & Punjab & 07 & 03 & 10 & 70.00 \\
\hline 6. & Kerala & 00 & 01 & 01 & 0 \\
\hline 7. & Tamilnadu & 01 & 01 & 02 & 50.00 \\
\hline 8. & West Bengal & 00 & 01 & 01 & 0 \\
\hline 9. & Gujarat & 02 & 01 & 03 & 66.66 \\
\hline \multirow[t]{2}{*}{10.} & New Delhi & 07 & 01 & 08 & 87.50 \\
\hline & & 122 & 27 & 149 & 81.87 \\
\hline
\end{tabular}

by two different laboratories by Fluorescent Antibody Virus Neutralization (FAVN) test. Shyamsundar et al. (2014) observed 84 percent vaccinated dogs showing protective neutralizing antibody titre by RFFIT. In contrast to this study, Neelufer et al. (2015) and Savaliya et al. (2015) reported low, viz. 58 and 62.36 percent of vaccinated dogs with protective neutralizing antibody titre by RFFIT, respectively.
The interval between vaccination and blood sampling is one of the main significant factors in determining host response. Rabies vaccination produces a typical antibody curve with response going down over the period. In this study, the best window period for sample collection was between 20 to 50 days of post vaccination which showed better protective neutralizing antibody titre percent i.e., 85.45 and 100 per cent in dogs and cats respectively

\section{Journal of Experimental Biology and Agriculture Science} http://www.jebas.org 
compared to short (<20 days) and long sampling days ( $>50$ days) of collection. This fact was earlier confirmed by researchers like Kennedy et al. (2007) and Mansfield et al. (2004).

The variation in production of neutralizing antibody response to length of interval of sampling following vaccination relates to response kinetics from primary vaccination. After primary vaccination, isotype shift from an Ig-M response to an Ig-G as immune response develops and optimum measurement in an appropriate window of time should measure this effect. Measurement at too early a stage captures only an Ig-M response, but will not confirm whether class switching to IgG response progresses. Measurement at later stage point of time may show lower antibody levels, but this may not relate to lack of immune protection. As the immunoglobulin measure may be proportionally more accounted for by Ig G (Kennedy et al., 2007).

The Chi square test in the present study, indicated the association between age and production of neutralizing antibodies against rabies where significant difference was observed between different age groups $(\mathrm{p}<0.05)$ in dogs. Ability of younger (< 1year) dogs and cats to develop protective neutralizing antibody titre is less compared to adult and older dogs. This could be attributed to immune system being less efficient (Kennedy et al., 2007). Mansfield et al. (2004) showed that animals less than one year old have an increased risk of having poor FAVN titres. Previous researchers like Aghomo et al. (1990), Kennedy et al. (2007) confirmed that young dogs can produce rabies antibodies from four weeks of age, when the titre of maternal antibody waned. This interference by maternal antibodies and less matured immune system explains the poorer immune response in young animals. Furthermore, in dogs it was observed that older dogs ( $>5$ years) revealed higher protective neutralizing antibody titre than adults (1-5years) and young (less than 1 year) dogs. This observation in contrast to Mansfield et al. (2004) and Kennedy et al. (2007), where they observed poor protective neutralizing antibody titre in older dogs than adults and opined that this may be due to reduction in immune regulation thought to occur.

HogenEsch et al. (2004) studied the effect of age on the immune response. However, they did not find any difference in $\operatorname{IgM}$ and IgG levels among the adult and old dogs. They confirmed prevaccination titre was higher in older dogs than in adults. Furthermore, they did not find any difference in post vaccination titre against rabies among adult and old dogs, this supports the findings of present study. The other possible explanation for higher protective neutralizing antibody titre in older dogs (94 percent) may be due to more number of booster vaccinations than the adults ( 76 percent) and young dogs (65 percent).

Influence of gender on neutralizing antibody titre in case of both dogs and cats was analysed by using chi square test which indicates that there is no significant difference $(p>0.05)$ between the titre of two different genders in both species of animals. This is in agreement with the study conducted by Mansfeild et al. (2004), Jakel et al. (2008), Shyamsundar et al. (2014), Savaliya et al. (2015) and Neelufer et al. (2015) in dogs. But contrasting results were observed by Mansfield et al. (2004) in case of vaccinated cats, where male cats showed lesser percentage of protective neutralizing antibody titre compared to females. This was attributed to suppression of cytokine production by gonadal steroid hormone (Schuurs \& Verheul., 1990; Rife et al.,1990; Verthelyi \& Klinman., 2000).

Various vaccine brands such as V1, V2, V3, V4, V5, V6, V7, V8 and V1, V2, V3, V4 were used in dogs and cats respectively. Of these, only brand V8 provided 100 per cent protection (9/9) and all the other vaccine brands except V1 (61.53 percent) and V7 (70 per cent) provided satisfactory seroconversion ranging from 75 percent (12/16 in V5) to 90.90 (10/11in V6). In cats, higher seroconversion was obtained by all vaccine brands. The performance of each vaccine brand vary as they are produced by different manufacturers having different formulation, concentration, integrity of antigen content, adjuvant and maintenance of cold chain until its use, as reported by Kennedy et al. (2007). Although there is apparent, relative variation in the performance of vaccine brands, the statistical analysis of vaccine brands and antibody titres by chi square test did not showed significant difference $(\mathrm{P}>0.05)$. Similar observations was recorded by Shyamsundar et al. (2014) and Savaliya et al. (2015). The contrasting reports on influence of vaccine brands on antibody titre were also reported by Mansfeild et al. (2004) and Neelufer et al. (2015).

In the present study, small breeds (50/60, 83.33 percent) compared to larger $(7 / 9,77.77$ percent $)$ and medium $(56 / 69,81.15$ per cent) sized breeds showed higher mean protective neutralizing antibody titres $(1.810 \mathrm{IU} / \mathrm{ml})$. However, there was no significant difference $(\mathrm{P}>0.05)$ in the titre of neutralizing antibodies among different breeds (based on size) when analysed by chi square test. Similar observations were recorded by Shyamsundar et al. (2014) and Savaliya et al. (2015). In contrast, to these results, Kennedy et al. (2007) observed five percent difference in log titre between breeds based on body size. There is clear existence of general relationship between the animal size and level of antibodies responses (Mansfield et al., 2004).The larger dogs are more likely to have deeper subcutaneous fat for injection, deposition and sequestration of rabies antigen known to reduce the level of immune response as compared to smaller breeds (Ellis, 1993; Keating \& Noble, 2003). In the present study, unequal sample size of breeds based on size may be the reason for not observing the difference among them.

Journal of Experimental Biology and Agriculture Science http://www.jebas.org 
Failure to protect 27 dogs even after vaccination is alarming and it may be attributed to single or multiple factors acting synergistically, like age, where 6/27 were found below one year of age, genetic profile of individual dog is different, as haplotype of specific breeds of dogs is a factor which leads to a difference in immune response to vaccination (Kennedy et al., 1999), reproductive status $(\mathrm{M}=17 / 19,89.5$ percent were intact, Female $=7 / 8,87.5$ were intact), brand of vaccine used and the inappropriate window period of serum sample collection in 74 percent $(20 / 27)$ of $\operatorname{dogs}$ that failed the test $(<20$ days $=3 / 27,11$ percent ; >50days $=17 / 27,63$ percent).

\section{Conclusion}

In the present study immune response of vaccinated domestic dogs and cats intended for pet-travel from India was studied by Rapid Fluorescent Focus Inhibition Test. The observed protective anti-rabies neutralizing antibody titre in dogs and cats were 81.87 and 100 per cent. Study showed that cats are better responders than dogs. The best window period for serum sampling is between 20 to 50 days post vaccination. Statistically, the age of the dog showed association for higher neutralizing antibody titre whereas gender, vaccine brands did not reveal any statistically significant association in conferring protective neutralizing antibody titre.

\section{Conflict of interest}

Authors would hereby like to declare that there is no conflict of interest that could possibly arise.

\section{References}

Aghomo HO, Oduye OO, Rupprecht CE (1990) The serological response of young dogs to the Flury LEP strain of rabies virus vaccine. Veterinary Research Communication $14: 415-425$.

Cliquet F, Verdier Y, Sagne L, Aubert M, Schereffer JL, Selve M, Wasniewski M, Servat A (2003) Neutralizing antibody titration in 25,000 sera of dogs and cats vaccinated against rabies in France, in the framework of the new regulations that offer an alternative to quarantine. Revue Scientifique Et Technique 22:857-66.

Ellis RW (1993) Editor. Hepatitis B Vaccines in clinical practice. Marcel Dekker.

Etessami R, Conzelmann KK, Fadai-Ghotbi B, Natelson H, Tsiang, Ceccaldi PE (2000) Spread and pathogenic characteristics of a $G$ deficient rabies virus recombinant: An invitro and invivo study. Journal of General Virology 81: 2147.

European Commission (2003) Regulation EC n॰998/2003 of the European parliament and the council of 26 May 2003 on the animal health requirements applicable to the non-commercial movements of pet animals and amending council directive 92/65/EEC.

Hampson K, Coudeville L, Lembo T, Sambo M, Kieffer A, Attlan M, Barrat J, Blanton JD, Briggs DJ, Cleaveland S, Costa P, Freuling CM, Hiby E, Knopf L, Leanes F, Meslin FX, Metlin A, Miranda ME, Müller T, Nel LH, Recuenco S, Rupprecht CE, Schumacher C, Taylor L, Vigilato MA, Zinsstag J, Dushoff J, Global Alliance for Rabies Control Partners for Rabies Prevention (2015) Estimating the global burden of endemic canine rabies. PLoS Negleted Tropical Diseases 9:e0003709. DOI: https://doi.org/10.1371/journal.pntd.0003709.

HogenEsch H, Thompson S, Dunham A, Ceddia M, Hayek M (2004) Effects of age on Immune parameters and the immune response of dogs to vaccines: a cross sectional study. Veterinary Immunology and Immunopathology 97:77-87.

IMNA (2010) Institute of Medicine of the National Academies, Global public health governance and the revised International Health Regulations. In: Relman DA, Choffness ER, Mack A (Eds.), Infectious Disease Movements in a Borderless World. National Academies Press, Washington, D. C.

Jackson AC (2016) Human Rabies : A 2016 update. Current Infectious Disease Reports 18:38.

Jakel V, Konig, M, Cussler K, Hanschmann K, Thiel HJ (2008) Factors influencing the antibody response to vaccination against rabies. Veterinary Record 154:423-6.

Keating GM, Noble S (2003) Noble S. Recombinant hepatitis B vaccine (Engerix-B): a review of its immunogenicity and protective efficacy against hepatitis B. Drugs 63:1021-51.

Kennedy LJ, Carter SD, Barnes A, Bell S, Bennett D, Ollier B, Thomson W (1999) Interbreed variation of DLA-DRB1,DQA1 alleles and haplotypes in the dog. Veterinary Immunology and Immunopathology 69:101-111.

Kennedy LJ, Lunt M, Barnes A, Mcelhinney L, Fooks AR, Baxter DN, Ollier WER (2007) Factors influencing the antibody response of dogs vaccinated against rabies. Vaccine 25:8500-8507.

Mansfield KL, Burr PD, Snodgrass DR, Sayers R, Fooks AR (2004) Factors affecting the serological response of dogs and cats to rabies vaccination. Veterinary Record 154: 423-426.

Neelufer MS, Isloor S, Veeresh BH, Palaniappan C, Sekhar B, Rathnamma D, Yathiraj S, Chandranaik BM, Deepti BR, Vishal, Manjunatha R (2015) Standardisation and application of rabies virus neutralization antibody assay for assessment of vaccinal 
efficacy in dogs, In: Compendium of $17^{\text {th }}$ national conference of APCRI, 4-5 ${ }^{\text {th }}$ July 2015.

OIE (2008) Manual of Diagnostic Tests and Vaccines for Terrestrial Animals (Mammals, Birds and Bees), O.I.E., Paris.

Perrin P, Thibodeau L, Sureau P (1985) Rabies immunosomes (subunit vaccine) structure \& immunogenicity, Pre-and postexposure protection studies. Vaccine 3: 325-332.

Rife SU, Marquez MG, Escalante A, Velich T (1990) The effect of testosterone on the immune response: Mechanism of action on antibody-forming cells. Immunological investigations 19: 259-270

Rupprecht CE, Hanlon CA, Hemachudha T (2002) Rabies Reexamined. Lancet Infectious Diseases 2: 327-343.

Savaliya BF, Mathakiya BB, Bhanderi, Jhala MK (2015) Evaluation of phenotypic factors for anti-rabies antibody in vaccinated pet dogs. Virus Disease 26:282-287.

Schuurs AH, Verheul HA (1990) Effect of gender and sex steroids on the immune response. Journal of Steroid Biochemistry 35:152-72.

Shyamsundar KA, Isloor S, Madhusudana SN, Mahesh V, Yathiraj S, Nandini VM, Rathnamma D, Veeregowda BM, Satyanarayana ML, Narayan Bhat M, Neelufer MS, Sharada R
(2014) In: Comparative evaluation of RFFIT and RABV Gprotein based ELISA for seromonitoring of anti-rabies vaccinal antibodies in domestic dogs in and around Bengaluru. $16^{\text {th }}$ National conference of Association for Prevention and Control of Rabies in India on $5^{\text {th }}-6^{\text {th }}$ July 2014.pp: 32.

Smith JS, Yager PA, Baer GM (1996) A rapid fluorescent focus inhibition (RFFIT) for determining rabies virus neutralizing antibody. In:"Laboratory Techniques in rabies", $4^{\text {th }}$ Edn, World health organization, Geneva.

Sudarshan MK (2017) Vision 2030: Dog-mediated human rabiesfree India: Action must begin now. Indian Journal of Public Health 61:1-2.

Sudarshan MK, Madhusudana SN, Mahendra BJ, Rao NS, Ashwath Narayana DH, Abdul Rahman S (2007) Assessing the burden of human rabies in India: Results of a national multi-center epidemiological survey. International Journal of Infectious Diseases 11:29-35.

Verthelyi D, Klinman DM (2000) Sex hormones correlate with the activity of cytokine-secreting cells in vivo. Immunology 100: 384-390.

WHO (2005) WHO Expert Consultation on Rabies. World Health Organisation, Geneva. 